\title{
Penerapan Metode Quantum Learning Tipe Kauny Quantum Memory Untuk Meningkatkan Hasil Belajar Mata Pelajaran Al-Qur'an Hadis
}

\author{
Romdloni $^{1 *}$ dan Malikin ${ }^{2}$ \\ ${ }^{12}$ STKIP Nurul Huda \\ *E-mail: romdloni@stkipnurulhuda.ac.id
}

\begin{abstract}
Abstrak
Tujuan penelitian ini adalah untuk mengetahui ada tidaknya peningkatan hasil belajar mata pelajaran Al-Qur'an Hadis setelah penerapan metode Quantum Learning Tipe Kauny Quantum Memory. Penelitian ini adalah penelitian tindakan kelas yang dilaksanakan dalam 3 siklus. Prosedur penelitian setiap siklus terdiri atas empat tahapan yaitu perencanaan, pelaksanaan, observasi dan refleksi. Subjek dari penelitian ini adalah siswa kelas VIII MTs NU Umbul Sari yang berjumlah 28 siswa. Teknik pengumpulan data menggunakan observasi dan tes, sedangkan teknik analisa data menggunakan teknik holberman yaitu reduksi, penyajian dan penarikan kesimpulan. Kesimpulan penelitian ini adalah pertama; hasil belajar sebelum penerapan metode adalah rendah yaitu dari 28 peserta didik terdapat 6 siswa atau 21,43\% mencapai ketuntasan dengan nilai rata-rata siswa 51,07. Kedua, hasil belajar mata pelajaran AI-Qur'an Hadis siswa setelah penerapan metode adalah baik yaitu dari 28 siswa terdapat 14 siswa atau 50\% yang mencapai ketuntasan dengan nilai rata-rata 62,86 pada siklus 1, terdapat 23 siswa atau 82,14\% mencapai ketuntasan dengan nilai rata-rata 73,57 pada siklus 2, dan 27 siswa atau 96,43\% dapat mencapai ketuntasan dengan nilai rata-rata 81,07 setelah tindakan siklus 3. Ketiga, Penerapan metode Quantum Learning Tipe Kauny Quantum Memory dapat meningkatkan hasil belajar Al-Qur'an Hadis setiap siklus sebesar 25\%.
\end{abstract}

\section{Kata kunci: Metode Quantum Learning Tipe Kauny Quantum Memory, Hasil Belajar, Al Qur'an Hadis}

\section{PENDAHULUAN}

Stándar kompetensi lulusan mata pelajaran Al-Qur'an Hadis tingkat Madrasah Tsanawiyah adalah memahami isi pokok Al-Qur'an, fungsi, dan bukti-bukti kemurniannya, istilah-istilah hadis, fungsi hadis terhadap Al-Qur'an, pembagian hadis ditinjau dari segi kuantitas dan kualitas, serta memahami dan mengamalkan ayat-ayat Al-Qur'an dan hadis tentang manusia dan tanggung jawab di muka bumi, demokrasi serta pengembangan ilmu pengetahuan dan teknologi (Kemendikbud, 2013:3). Keberhasilan dan ketercapaian standar kelulusan sebagaimana tersebut ditandai dengan pencapaian hasil belajar siswa. Belajar dikatakan telah berhasil apabila seseorang telah belajar akan terjadi perubahan tingkah laku pada orang tersebut, misalnya dari tidak tahu menjadi tahu dan dari tidak mengerti menjadi mengerti. Hasil belajar merupakan umpan balik dari kegiatan proses pembelajaran. Sehubungan dengan hal tersebut maka Prayitno (2013:33) mengatakan, "Hasil belajar adalah suatu yang diperoleh, dikuasai atau merupakan hasil dari proses belajar". Jadi Hasil belajar merupakan perubahan perilaku pada diri seseorang akibat tindak belajar yang mencakup aspek kognitif, aspek afektif, dan aspek psikomotorik.(Marlina Marlina; Sayid Amrullah, 2017)

Hasil belajar yang diperoleh siswa bukanlah hanya berdasarkan kemampuan intelektual siswa semata, melainkan banyak faktor-faktor yang mempengaruhi hasil belajar tersebut. Slameto (2010:54) menjelaskan faktor-faktor yang mempengaruhi pencapaian hasil belajar sebagai berikut:

Faktor yang mempengaruhi prestasi belajar dapat digolongkan menjadi dua golongan yaitu faktor intern dan faktor ekstern. Faktor intern adalah faktor dalam diri individu sedang belajar, sedangkan faktor ekstern adalah faktor di luar individu seperti penggunaan metode maupun pendekatan belajar. Masing-masing faktor tersebut saling terkait satu dengan lainnya 
sehingga masing-masing faktor harus mendukung serta melengkapi faktor lainnya. Faktor dari dalam merupakan faktor bawaan sedangkan faktor dari luar merupakan faktor pelayanan.

Berdasarkan penjelasan tersebut, metode pembelajaran merupakan salah satu faktor yang mempengaruhi pencapaian hasil belajar siswa. Oleh karena itu setiap guru harus mampu memilih dan menerapkan metode pembelajaran dengan baik. Hal tersebut sebagaimana dikemukakan Djamarah (2008:30) bahwa "Seorang guru tidak akan berhasil dalam pembelajarannya kecuali menguasai model belajar, pendekatan belajar serta metode belajar dengan baik". Ungkapan sebagaimana tersebut menunjukkan bahwa metode pembelajaran adalah sarana penting yang menentukan tingkat keberhasilan belajar siswa.

Metode pembelajaran sebagai salah satu faktor penentu keberhasilan belajar berlaku untuk semua mata pelajaran tidak terkecuali pada mata pelajaran Al-Qur'an Hadis. Apabila guru kurang dapat memahami kondisi siswa serta menciptakan kondisi pembelajaran yang menyenangkan melalui penerapan metode secara aktif dan kreatif akan mengakibatkan materi pembelajaran kurang dapat dipahami sehingga akan berimplikasi pada rendahnya hasil belajar siswa. Hal tersebut sebagaimana terjadi di MTs NU Umbul Sari khususnya di kelas VIII pada mata pelajaran AI-Qur'an Hadis. Berdasarkan hasil pengamatan pendahuluan pada hari Senin tanggal 30 Januari 2017 diketahui bahwa proses pembelajaran Al-Qur'an Hadis di kelas VIII belum maksimal yang ditandai dari sebagian kecil siswa terlibat aktif selama pembelajaran. Siswa hampir tidak pernah bertanya kepada guru dan hanya sesekali menjawab pertanyaan guru.

Mata pelajaran AI-Qur'an Hadis di kelas VIII MTs NU Umbul Sari dilaksanakan menggunakan metode pembelajaran tradisional yaitu dengan cara memberikan catatan, menjelaskan materi pembelajaran dengan teknik ceramah, menugaskan siswa menghafal ayat Al-Qur'an maupun hadis Nabi Muhammad SAW, kemudian memberikan evaluasi. Kegiatan pembelajaran tersebut mengkibatkan pemahaman siswa terhadap materi pembelajaran menjadi rendah. Hal tersebut sebagaimana hasil dokumentasi nilai midle semester gazal yang menunjukkan dari 26 siswa hanya terdapat 7 orang siswa atau $26,92 \%$ mencapai ketuntasan, sedangkan 19 siswa atau $73,08 \%$ belum mencapai ketuntasan 70.

Berdasarkan kondisi pembelajaran Al-Qur'an Hadis di kelas VIII-2 MTs NU Umbul Sari sebagaimana tersebut, peneliti bermaksud mengadakan suatu penelitian berbentuk tindakan kelas. Pada penelitian ini dipilih metode pembelajaran Quantum Learning tipe Kauny Quantum Memory. Herwibowo (2013:1) mengungkapkan, "Quantum Learning tipe Kauny Quantum Memory adalah metode pembelajaran yang menggunakan memori untuk meningkatkan pemahaman terhadap materi pembelajaran". Definisi tersebut menunjukkan Quantum Learning tipe Kauny Quantum Memory merupakan inti dari perkembangan kognitif, sebab segala bentuk belajar dari individu melibatkan memori atau daya ingat siswa. Siswa melalui memori ingatan dapat menyimpan informasi yang diterima sepanjang waktu. Penekanan pelaksanaan Quantum Learning ialah menciptakan suasana belajar menyenangkan serta mengubah kemampuan dan bakat alamiah siswa menjadi satu pengetahuan utuh. Quantum Learning merupakan orkestrasi bermacam-macam interaksi untuk mendesain suatu proses belajar menyenangkan sesuai tingkat perkembangan siswa. 
Tipe Kauny Quantum Memory pada dasarnya adalah metode menghafal Al-Qur'an yang dikembangkan oleh ustad Bobby Herwibowo, Lc. Kauny Quantum Memory merupakan sebuah metode atau teknik cepat menghapal Al-Qur'an dengan mengoptimalkan kemampuan otak kanan untuk menangkap visualisasi makna, arti dan kait dari ayat-ayat yang dihafal. Metode ini cukup mudah diikuti, ringan dan menyenangkan serta tidak memerlukan waktu lama untuk menghafal. Penerapan Quantum Learning tipe Kauny Quantum Memory memudahkan siswa dalam menghafalkan ayat atau hadis, fahmul maani atau memahami makna ayat maupun hadis yang dihafal, memahami makharijul khuruf, serta menjadikan siswa mahir kitabah atau menulis huruf AlQur'an.

Pemilihan metode pembelajaran Quantum Learning tipe Kauny Quantum Memory didasarkan pada asumsi bahwa metode pembelajaran Quantum Learning tipe Kauny Quantum Memory merupakan satu bentuk model pembelajaran berbasis aktivitas belajar siswa. Penerapan metode pembelajaran Quantum Learning tipe Kauny Quantum Memory memungkinkan siswa dapat berlatih memahami berbagai ayat Al-Qur'an maupun hadis Nabi Muhammad SAW pada pembelajaran AlQur'an Hadis dengan berbagai teknik tertentu seperti saling menjelaskan untuk bertukar pemahaman. Oleh karena itu, penerapan metode pembelajaran Quantum Learning model Kauny Quantum Memory diharapkan dapat meningkatkan hasil belajar mata pelajaran AI-Qur'an Hadis siswa kelas VIII MTs NU Umbul Sari.

\section{METODE/EKSPERIMEN}

Penelitian ini merupakan bentuk penelitian tindakan kelas atau disebut dengan classroom in action research. Kasihani (2012:44) menjelaskan, "Penelitian tindakan kelas adalah penelitian yang bertujuan untuk memperbaiki kekurangan-kekurangan dalam pembelajaran di kelas dengan cara melakukan tindakan tertentu". Upaya tindakan untuk perbaikan dimaksudkan sebagai pencarian jawab atas permasalahan yang dialami guru dalam melaksanakan tugasnya sehari-hari. Jadi masalah-masalah yang diungkap dan dicarikan jalan keluar dalam penelitian adalah masalah yang benar-benar ada dan dialami oleh guru. Penelitian tindakan kelas adalah suatu pengamatan yang menerapkan tindakan didalam kelas dengan menggunakan aturan sesuai dengan metodologi penelitian yang dilakukan dalam beberapa periode atau siklus. Pemilihan metode tindakan kelas didasarkan pada maksud penelitian yaitu untuk memperbaiki proses dan hasil belajar mata pelajaran Al-Qur'an hadis siswa kelas VIII MTs NU Umbul Sari Kecamatan Buay Madang melalui penerapan metode pembelajaran Quantum Learning tipe Kauny Quantum Memory.

Penelitian tindakan merupakan proses yang dinamis dengan empat momen, yaitu perencanaan, tindakan, observasi dan refleksi berbentuk spiral. Penelitian tindakan kelas memiliki berbagai desain yang salah satunya dan akan digunakan pada penelitian ini adalah desain penelitian Stephen Kemmis. Model desain penelitian tindakan Stephen Kemmis digunakan model refleksi-diri (self-reflective) berbentuk spiral, yang setiap siklusnya terdiri atas perencanaan, tindakan, observasi, dan refleksi. Objek penelitian ini adalah proses pembelajaran Al-Qur'an hadis melalui penerapan metode pembelajaran Quantum Learning tipe Kauny Quantum Memory di kelas VIII MTs NU Umbul Sari Kecamatan Buay Madang Kabupaten OKU Timur. Pembelajaran dilaksanakan melalui penelitian 
tindakan dalam siklus-siklus berkelanjutan melalui empat tahapan yaitu perencanaan, pelaksanaan, observasi dan refleksi. Subjek dari penelitian ini adalah siswa kelas VIII MTs NU Umbul Sari Kecamatan Buay Madang Kabupaten OKU Timur yang berjumlah 26 siswa dengan perincian 16 siswa laki-laki dan 10 siswa perempuan.

Data-data penelitian dikumpulkan melalui berbagai pendekatan atau teknik tertentu. Teknik pengumpulan data pada penelitian ini adalah observasi dan tes. Pada umumnya analisis kualitatif terhadap data penelitian tindakan kelas dapat dilakukan melalui tahap menyeleksi, menyederhanakan, mengklasifikasi, memfokuskan, mengorganisasi, membuat abstraksi atas kesimpulan makna hasil analisis. Analisis data dilakukan melalui tiga tahap yaitu reduksi data, penyajian data, serta verifikasi atau penarikan kesimpulan. Setelah nilai rata-rata siswa diketahui, langkah selanjutnya adalah menghitung prosentase ketuntasan belajar siswa. Sukardi (2006:96) mengemukakan, "Ketuntasan belajar atau daya serap merupakan pencapaian taraf penguasaan minimal yang telah ditetapkan guru dalam tujuan pembelajaran setiap satuan pelajaran". Ketuntasan belajar siswa pada penelitian ini meliputi ketuntasan belajar individual dan klasikal. Ketuntasan belajar individual ditetapkan bahwa siswa dikatakan tuntas apabila memperoleh nilai $\geq 70$, sedangkan secara klasikal pembelajaran dikatakan tuntas apabila 90\% dari jumlah siswa seluruhnya telah memperoleh nila $\geq 70$. Perhitungan prosentase ketuntasan belajar dilakukan menggunakan rumus berikut:

KB $=\frac{\text { Jumlah Siswa Mencapai KKM }}{\text { Jumlah Siswa Seluruhnya }}$ (Sukardi, 2006:78).

Analisis data tersebut diperoleh berdasarkan hasil tindakan pada setiap siklus. Hasil tindakan pada setiap siklus dibandingkan dengan hasil tes awal untuk mengetahui presentase peningkatan hasil belajar mata pelajaran Al-Qur'an hadis siswa. Setiap siklus diupayakan adanya peningkatanpeningkatan perolehan skor hasil belajar siswa untuk menunjukkan efektivitas pembelajaran. Ketuntasan yang hendak dicapai adalah 90\% dari jumlah siswa keseluruhan telah mencapai KKM ditetapkan yaitu 70 .

Hasil tindakan pada setiap siklus dibandingkan dengan hasil tes awal untuk mengetahui presentase peningkatan hasil belajar mata pelajaran IPS siswa. Setiap siklus diupayakan adanya peningkatan-peningkatan perolehan skor hasil belajar siswa untuk menunjukkan efektivitas pembelajaran. Keberhasilan tindakan atau ketuntasan tindakan pada penelitian ini adalah:

1) Ketuntasan belajar siswa mencapai $90 \%$ secara klasikal.

2) Aktivitas belajar siswa mencapai $90 \%$ secara klasikal.

3) Aktivitas guru selama pembelajaran telah mencapai $90 \%$.

\section{HASIL DAN PEMBAHASAN}

Penelitian tindakan kelas ini bermula dari hasil observasi pendahuluan yang dilaksanakan dalam pembelajaran AI Qur'an Hadis di kelas VIII MTs NU Umbul Sari Kecamatan Buay Pemuka Bangsa Raja. Berdasarkan hasil observasi pendahuluan diketahui bahwa pembelajaran Al Qur'an Hadis di kelas VIII MTs NU Umbul Sari Kecamatan Buay Pemuka Bangsa Raja dilaksanakan dengan menggunakan metode pembelajaran atau teknik pembelajaran ceramah konvensional sehingga 
pembelajaran bersifat verbalistis. Keadaan pembelajaran demikian menjadikan aktivitas belajar serta hasil belajar siswa kelas VIII MTs NU Umbul Sari Kecamatan Buay Pemuka Bangsa Raja menjadi rendah.

Setelah diadakan penelitian yang terdiri dari tiga siklus dan ditempuh dalam 3 kali pertemuan dengan alokasi waktu 6 jam pelajaran diperoleh hasil sebagai berikut:

\section{Aktivitas Belajar Siswa Kelas VIII MTs NU Umbul Sari Kecamatan Buay Pemuka Bangsa Raja}

Aktivitas belajar siswa selama pembelajaran Al Qur'an Hadis di kelas VIII MTs NU Umbul Sari Kecamatan Buay Pemuka Bangsa Raja menunjukkan adanya peningkatan dari satu siklus perbaikan pembelajaran ke siklus berikutnya. Untuk lebih jelasnya peningkatan aktivitas belajar dalam setiap siklus dapat dilihat pada tabel 1 berikut:

Tabel 1

Peningkatan Aktivitas Belajar Siswa Setiap Siklus

\begin{tabular}{|c|c|c|c|c|c|}
\hline No & No Absen & Pra Siklus & Siklus 1 & Siklus 2 & Siklus 3 \\
\hline 1 & 01 & 4 & 6 & 10 & 12 \\
\hline 2 & 02 & 3 & 7 & 9 & 10 \\
\hline 3 & 03 & 4 & 5 & 8 & 10 \\
\hline 4 & 04 & 3 & 4 & 10 & 12 \\
\hline 5 & 05 & 5 & 8 & 8 & 10 \\
\hline 6 & 06 & 4 & 6 & 11 & 12 \\
\hline 7 & 07 & 5 & 7 & 8 & 9 \\
\hline 8 & 08 & 3 & 6 & 9 & 12 \\
\hline 9 & 09 & 5 & 6 & 7 & 11 \\
\hline 10 & 10 & 3 & 7 & 9 & 10 \\
\hline 11 & 11 & 3 & 7 & 8 & 12 \\
\hline 12 & 12 & 5 & 8 & 9 & 10 \\
\hline 13 & 13 & 5 & 6 & 8 & 11 \\
\hline 14 & 14 & 4 & 6 & 9 & 12 \\
\hline 15 & 15 & 5 & 5 & 7 & 11 \\
\hline 16 & 16 & 3 & 7 & 12 & 12 \\
\hline 17 & 17 & 4 & 4 & 10 & 12 \\
\hline 18 & 18 & 5 & 5 & 6 & 9 \\
\hline 19 & 19 & 6 & 6 & 8 & 10 \\
\hline 20 & 20 & 3 & 8 & 12 & 12 \\
\hline 21 & 21 & 5 & 5 & 8 & 11 \\
\hline 22 & 22 & 4 & 4 & 10 & 12 \\
\hline 23 & 23 & 4 & 8 & 10 & 11 \\
\hline 24 & 24 & 5 & 5 & 9 & 12 \\
\hline 25 & 25 & 4 & 7 & 8 & 10 \\
\hline 26 & 26 & 6 & 6 & 10 & 11 \\
\hline 27 & 27 & 4 & 7 & 8 & 10 \\
\hline & Jumlah & $\mathbf{1 1 7}$ & $\mathbf{1 7 2}$ & $\mathbf{2 5 2}$ & $\mathbf{3 0 8}$ \\
\hline & $\mathbf{2}$ & $\mathbf{6}$ & $\mathbf{1 4}$ & $\mathbf{9 , 0 0}$ & $\mathbf{1 1 , 0 0}$ \\
\hline Pera-rata & $\mathbf{4 , 1 8}$ & $\mathbf{5 1 , 1 9}$ & $\mathbf{7 5 , 0 0}$ & $\mathbf{9 1 , 6 7}$ \\
\hline & & $\mathbf{3 4 , 8 2}$ & & & \\
\hline
\end{tabular}

Berdasarkan tabel 4.25 diketahui bahwa terjadi peningkatan aktivitas belajar siswa kelas VIII MTs NU Umbul Sari Kecamatan Buay Pemuka Bangsa Raja. Tindakan menggunanaka metode pembelajaran Quantum Learning Tipe Kaunny Quantum Memory secara nyata dapat 
meningkatkan aktivitas belajar siswa. Peningkatan persentase hasil observasi aktivitas belajar siswa setiap siklus dihitung sebagai berikut:

$\mathrm{M}=\frac{\text { (Siklus 3-siklus 2)+(siklus 2-siklus 1)+(siklus 1-prasiklus) }}{3}$ (Muslich, 2011:76).

$$
\begin{aligned}
& =\frac{(91,67 \%-75,00 \%)+(75,00 \%-51,19 \%)+(51,19 \%-34,82 \%)}{3} \\
& =\frac{16,67 \%+23,81 \%+16,37 \%}{3} \\
& =\frac{56,85 \%}{3} \\
& =18,95 \%
\end{aligned}
$$

Berdasarkan perhitungan sebagaimana tersebut diketahui bahwa peningkatan aktivitas belajar mata pelajaran Al Qur'an Hadis materi pembelajaran Tamak Terhadap Harta siswa kelas VIII MTs NU Umbul Sari melalui penerapan metode pembelajaran Quantum Learning Tipe Kaunny Quantum Memory adalah 18,95\%. Oleh karena itu dapat disimpulkan bahwa penerapan metode pembelajaran Quantum Learning Tipe Kaunny Quantum Memory dapat meningkatkan aktivitas belajar siswa sebesar 18,95\% pada setiap siklusnya. Lebih jelasnya peningkatan aktivitas belajar siswa kelas VIII MTs NU Umbul Sari Kecamatan Buay Pemuka Bangsa Raja melalui penerapan metode pembelajaran Quantum Learning Tipe Kaunny Quantum Memory dapat dilihat pada gambar 1 berikut:

\section{Gambar 1}

Peningkatan Aktivitas Belajar Siswa Setiap Siklus

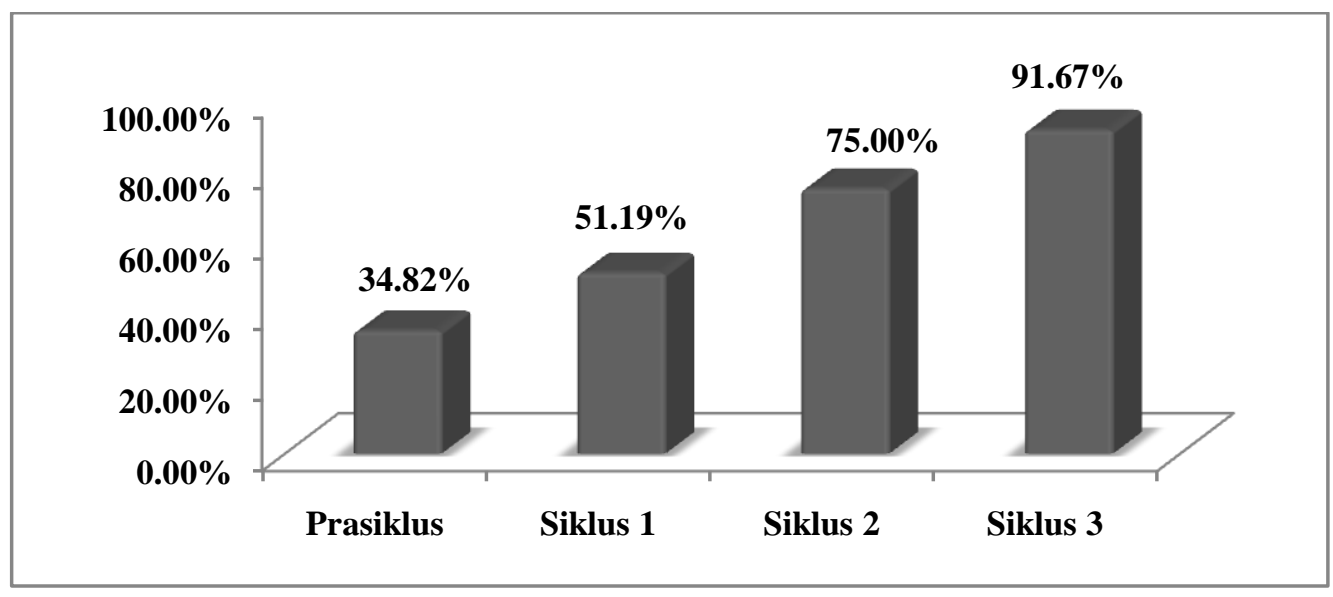

Gambar 1 menunjukkan bahwa aktivitas belajar siswa mengalami peningkatan pada setiap siklusnya. Data sebagaimana tersebut menunjukkan bahwa metode pembelajaran Quantum Learning Tipe Kaunny Quantum Memory efektif diterapkan pada mata pelajaran Al Qur'an Hadis kelas VIII MTs NU Umbul Sari Kecamatan Buay Pemuka Bangsa Raja Kabupaten OKU Timur.

\section{Peningkatan Aktivitas Guru dalam Pembelajaran Setiap Siklus}

Hasil penelitian menunjukkan bahwa selain dapat meningkatkan aktivitas belajar siswa, tindakan penelitian melalui penerapan metode pembelajaran Quantum Learning Tipe Kaunny Quantum Memory dapat meningkatkan aktivitas guru pada setiap siklus. Hal tersebut sebagaimana rekapitulasi hasil observasi aktivitas guru yang disajikan pada tabel 2 berikut: 
Tabel 2

Rekapitulasi Peningkatan Aktivitas Guru Setiap Siklus

\begin{tabular}{|c|c|c|c|c|}
\hline Aspek & Prasiklus & Siklus 1 & Siklus 2 & Siklus 3 \\
\hline Jumlah & 14 & 24 & 29 & 50 \\
\hline Rata-rata & 1,08 & 1,85 & 3,00 & 3,85 \\
\hline Persentase & $26,92 \%$ & $46,15 \%$ & $75 \%$ & $96,15 \%$ \\
\hline
\end{tabular}

Tabel 4.26 menunjukkan bahwa terjadi peningkatan aktivitas guru dalam mengelola kegiatan pembelajaran pada setiap siklusnya. Peningkatan persentase hasil observasi aktivitas guru dalam pembelajaran setiap siklus dihitung sebagai berikut:

$\mathrm{M}=\frac{(\text { Siklus 3-siklus 2) }+(\text { siklus 2-siklus 1) }+(\text { siklus 1-prasiklus })}{3}$ (Muslich, 2011:76).

$$
\begin{aligned}
& =\frac{(96,15 \%-75,00 \%)+(75,00 \%-46,15 \%)+(46,15 \%-26,92 \%)}{3} \\
& =\frac{21,15 \%+28,85 \%+19,23 \%}{3} \\
& =\frac{69,23 \%}{3} \\
& =23,08 \%
\end{aligned}
$$

Berdasarkan perhitungan sebagaimana tersebut diketahui bahwa peningkatan aktivitas guru dalam mengelola pembelajaran mata pelajaran Al Qur'an Hadis materi pembelajaran Tamak Terhadap Harta di kelas VIII MTs NU Umbul Sari melalui penerapan metode pembelajaran Quantum Learning Tipe Kaunny Quantum Memory adalah 23,08\%. Oleh karena itu dapat disimpulkan bahwa penerapan metode pembelajaran Quantum Learning Tipe Kaunny Quantum Memory dapat meningkatkan aktivits guru dalam pembelajaran sebesar 23,08\% pada setiap siklusnya. Lebih jelasnya peningkatan aktivitas guru dalam pembelajaran Al Qur'an Hadis di kelas VIII MTs NU Umbul Sari Kecamatan Buay Pemuka Bangsa Raja melalui penerapan metode pembelajaran Quantum Learning Tipe Kaunny Quantum Memory dapat dilihat pada gambar 2 berikut:

\section{Gambar 2}

\section{Peningkatan Aktivitas Guru dalam Pembelajaran Setiap Siklus}

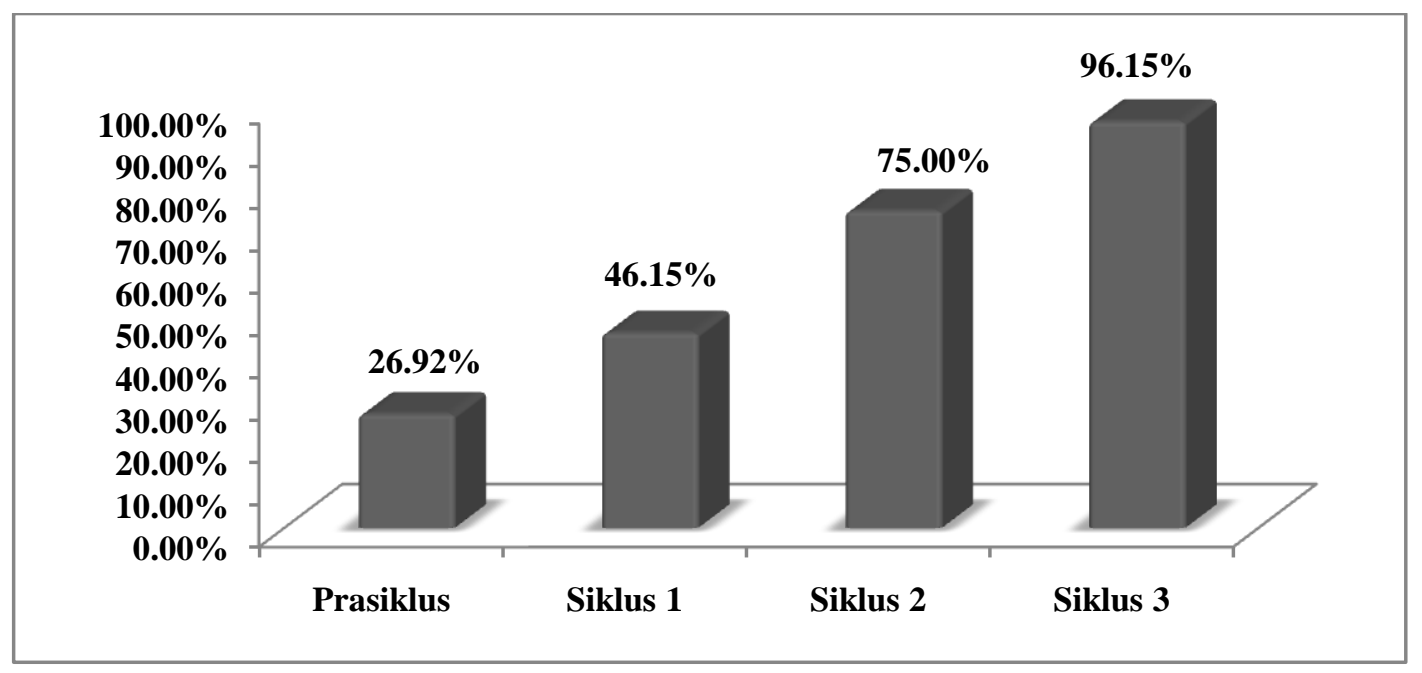


Gambar 2 menunjukkan bahwa aktivitas belajar siswa mengalami peningkatan pada setiap siklusnya. Data sebagaimana tersebut menunjukkan bahwa metode pembelajaran Quantum Learning Tipe Kaunny Quantum Memory efektif diterapkan pada mata pelajaran Al Qur'an Hadis kelas VIII MTs NU Umbul Sari Kecamatan Buay Pemuka Bangsa Raja Kabupaten OKU Timur.

\section{Peningkatan Hasil Belajar Mata Pelajaran Al Qur'an Hadis Siswa Setiap Siklus}

Tindakan perbaikan pembelajaran menggunakan metode pembelajaran Quantum Learning Tipe Kaunny Quantum Memory dalam pembelajaran Al Qur'an Hadis mampu meningkatkan hasil belajar siswa kelas VIII MTs NU Umbul Sari Kecamatan Buay Pemuka Bangsa Raja pada setiap siklusnya. Penerapan metode pembelajaran Quantum Learning Tipe Kaunny Quantum Memory menjadikan siswa dapat mengimplementasikan materi pembelajaran dalam menyelesaikan soal. Pelatihan kelompok melalui kegiatan diskusi kemudian berbagi menjadikan siswa terlatih serta memiliki keberanian untuk mengungkapkan berbagai kemampuan yang dimilikinya. Peningkatan hasil belajar mata pelajaran AI Qur'an Hadis siswa kelas VIII MTs NU Umbul Sari Kecamatan Buay Pemuka Bangsa Raja sebagaimana tersebut dapat dilihat pada gambar 3 berikut:

Gambar 3

Peningkatan Hasil Belajar Siswa Setiap Siklus

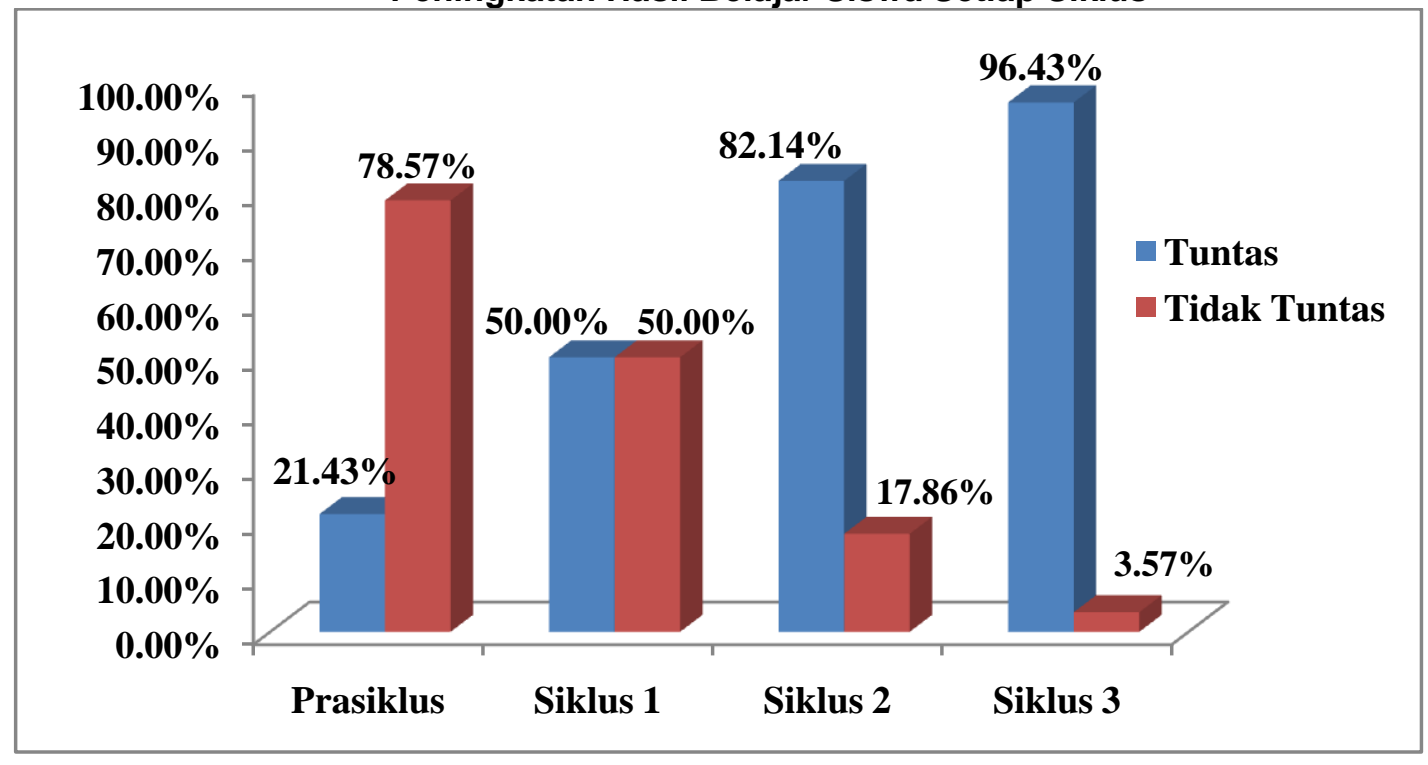

Gambar 3 menunjukkan bahwa hasil belajar siswa mengalami peningkatan pada setiap siklusnya. Berdasarkan hasil penelitian prasiklus, siklus 1 , siklus 2, dan siklus 3 maka dapat diambil pemahaman bahwa kegiatan pembelajaran mata pelajaran Al Qur'an Hadis di kelas VIII MTs NU Umbul Sari Kecamatan Buay Pemuka Bangsa Raja melalui penerapan metode pembelajaran Quantum Learning Tipe Kaunny Quantum Memory mengalami peningkatan pada setiap siklusnya. Peningkatan terjadi pada aktivitas belajar siswa, aktivitas guru mengelola pembelajaran, serta hasil belajar siswa. Oleh karena itu, dapat dikatakan bahwa metode pembelajaran Quantum Learning Tipe Kaunny Quantum Memory efektif diterapkan pada pembelajaran AI Qur'an Hadis di kelas VIII MTs NU Umbul Sari Kecamatan Buay Pemuka Bangsa Raja.

Hasil penelitian menunjukkan bahwa metode pembelajaran Quantum Learning Tipe Kaunny Quantum Memory efektif untuk diterapkan pada pembelajaran Al Qur'an Hadis. Metode 
pembelajaran Quantum Learning Tipe Kaunny Quantum Memory memberikan pengalaman kepada siswa untuk berpikir dan mengulangi kembali materi pembelajaran yang telah disampaikan sehingga siswa akan benar-benar memahami materi pembelajaran. Hal tersebut sebagaimana dikemukakan De Porter (2009:180) mengungkapkan, "Metode pembelajaran Quantum Learning Tipe Kaunny Quantum Memory adalah metode pembelajaran yang memaksimalkan pemberdayaan pikiran dan perasaan dengan pola bertambah dan mengulang". Metode pembelajaran Quantum Learning Tipe Kaunny Quantum Memory atau strategi belajar memutar pada dasarnya menitikberatkan pada cara-cara memperkuat dorongan-dorongan internal untuk memahami dunia dengan cara menggali dan mengordinasikan data, merasakan adanya masalah dan mengupayakan jalan pemecahannya. Model belajar memutar karena siswa benar-benar menempuh informasi dalam pola yang sama setiap hari.

Berdasarkan penelitian yang telah dilaksanakan diketahui metode pembelajaran Quantum Learning Tipe Kaunny Quantum Memory memiliki kelebihan utama yaitu adanya kondisi tenang yang tercipta dalam pembelajaran. Ketenangan akan memacu siswa lebih berkonsentrasi selama pembelajaran. Selain itu, kelebihan metode pembelajaran Quantum Learning Tipe Kaunny Quantum Memory terletak pada terbinanya kreatifitas siswa dengan belajar melalui peta konsep serta membuat catatan secara mandiri sesuai peta konsep yang disajikan oleh guru. Dengan demikian, siswa akan lebih berkonsentrasi mengikuti kegiatan pembelajaran dan lebih mudah memahami materi pembelajaran sehingga dapat meraih hasil belajar secara maksimal.

\section{PENUTUP}

Berdasarkan hasil penelitian yang telah dipaparkan dapat disimpulkan sebagai berikut.

1. Hasil belajar mata pelajaran Al Qur'an Hadis siswa sebelum penerapan metode Quantum Learning Tipe Kauny Quantum Memory di kelas VIII MTs NU Umbul Sari Tahun Pelajaran 2017/ 2018adalah rendah yaitu dari 28 peserta didik hanya terdapat 6 siswa atau 21,43\% mencapai ketuntasan dengan nilai rata-rata siswa 51,07.

2. Hasil belajar mata pelajaran Al Qur'an Hadis siswa setelah penerapan metode Quantum Learning Tipe Kauny Quantum Memory di kelas VIII MTs NU Umbul Sari Tahun Pelajaran 2017/ 2018adalah baik yaitu dari 28 siswa terdapat 14 siswa atau 50\% yang mencapai ketuntasan dengan nilai rata-rata 62,86 pada siklus 1 , terdapat 23 siswa atau $82,14 \%$ mencapai ketuntasan dengan nilai rata-rata 73,57 pada siklus 2, dan 27 siswa atau 96,43\% dapat mencapai ketuntasan dengan nilai rata-rata 81,07 setelah tindakan siklus 3 .

3. Penerapan metode Quantum Learning Tipe Kauny Quantum Memory dapat meningkatkan hasil belajar Al Qur'an Hadis siswa kelas VIII MTs NU Umbul Sari Tahun Pelajaran 2017/ 2018setiap siklus sebesar $25 \%$.

\section{UCAPAN TERIMAKASIH}

Peneliti mengucapkan terima kasih kepada LPPM STKIP Nurul Huda Sukaraja OKU Timur, MTs NU Umbul Sari dan Tim Jurnal Al I'tibar Program Studi PAI STKIP Nurul Huda. 


\section{DAFTAR PUSTAKA}

Aly, Herry Noer. 2008. Metodologi Pembelajaran Agama Islam. Jakarta: Amisco.

De Porter, Bobbi. 2000. Terapan Quantum Teaching. Jakarta: Impressario.

Djamarah, Syaiful Bahri. 2008. Psikologi Belajar. Jakarta: Rineka Cipta.

Hanafiah, Nanang. 2009. Reaktualisasi Strategi Pembelajaran Pendidikan Agama Islam. Bandung: Refika Aditama.

Herwibowo. 2013. Kaunny Quantum Memory. Jakarta: Gava Media.

Kasihani. 2012. Praktek Penelitian Tindakan Kelas. Palembang: IAIN Raden Fattah.

Kemendikbud. 2013. Kurikulum Pembelajaran Al-Qur'an Hadis 2013. Jakarta: Erlangga.

Marlina Marlina; Sayid Amrullah. (2017). Perbandingan Efektivitas Social Interaction Models Dan Personal Family Models Dalam Meningkatkan Hasil Belajar Pendidikan Agama Islam. Al I'tibar: Jurnal Pendidikan Islam, 4(1), 35-49.

Muslich, Mansur. 2010. Melaksanakan PTK Itu Mudah. Jakarta: Bumi Aksara.

Prayitno, Dani. 2013. Dasar-dasar Evaluasi Pendidikan. Bandung: Remaja Rosdakarya.

Slameto. 2010. Belajar dan Faktor yang Mempengaruhinya. Jakarta: Rineka Cipta.

Subhan, Nabhan. 2009. Model Pembelajaran Inovatif. Jakarta: Ganesha.

Sukardi. 2006. Metode Penelitian untuk Pendidikan. Jakarta: Raja Grafindo Persada. 